Research Article

\title{
Supplementation of Microbial Phytase with Safflower Meal in Rainbow Trout (Oncorhynchus mykiss): The Effects on Growth, Digestibility, Environmental, and Serum Biological Parameters
}

\author{
İsmail Berat Çantaş (iD and Önder Yildirim \\ Mugla Sitki Kocman University, Faculty of Fisheries, Department of Aquaculture, 48000 Muğla, Turkey \\ Correspondence should be addressed to Önder Yildirim; onderyildirim@mu.edu.tr
}

Received 6 February 2020; Revised 5 April 2020; Accepted 9 June 2020; Published 8 July 2020

Guest Editor: Francesca Arfuso

Copyright ( 2020 İsmail Berat Çantaş and Önder Yildirim. This is an open access article distributed under the Creative Commons Attribution License, which permits unrestricted use, distribution, and reproduction in any medium, provided the original work is properly cited.

\begin{abstract}
This study aimed to determine the effects of diets replacing soybean meal with safflower meal and phytase enzyme on feed utilization, growth performance, body composition, serum biological parameters, and environmental effects of rainbow trout (Oncorhynchus mykiss). To this aim, five different isonitrogenous (44\%) and isocaloric (23 kJ) experimental feeds were formulated as follows: the control group (C) containing no safflower meal and enzyme; SFM10 and SFM20 groups containing $10 \%$ and $20 \%$ of safflower meal instead of soybean meal, respectively; and SFM10 $\pm \mathrm{P}_{1000}$ and SFM $20 \pm \mathrm{P}_{2000}$ groups containing $10 \%$ safflower meal and $1000 \mathrm{IU} / \mathrm{kg}$ phytase and $20 \%$ safflower meal and $2000 \mathrm{IU} / \mathrm{kg}$ phytase, respectively. Juveniles $(12.57 \pm 3.05 \mathrm{~g}$ average weight) were fed for 60 days. As a result, the best growth rate and feed conversion were recorded in the SFM20 $\pm \mathrm{P}_{2000}$ group with $127.07 \pm 7.73 \%$ and $1.13 \pm 0.020$, respectively $(p<0.05)$. On the contrary, total phosphorus in SFM $20 \pm \mathrm{P}_{2000}$ group trial feed was $1.20 \pm 0.02$, while $0.70 \pm 0.08$ was found in feces that is the best result between other groups. ALP, LDH, TPROT, CHOL, and triglyceride levels were not statistically different among the experimental groups. ALT, AST, glucose, and albumin levels in serum resulted to be affected by different phytase levels but without any negative effect on fish growth and fish health status. Cholesterol level in the SFM10 $\pm \mathrm{P}_{1000}$ group was the highest and positively affected growth and health status of this group. In conclusion, $20 \%$ safflower meal replacement along with $2000 \mathrm{IU} / \mathrm{kg}$ microbial phytase in feeds can be considered suitable for rainbow trout due to its sustainability and reduced environmental effects due to reduced phosphorous excretion.
\end{abstract}

\section{Introduction}

Aquaculture production is one of the most important economic sectors worldwide. The global aquaculture production in 2016 was about 80 million tons in the world with 814,090 tons only of rainbow trout and about 178,000 tons production only in Europe [1]. In Turkey, the annual aquaculture production was 314,537 tons in 2018 with 108,450 tons of rainbow trout [2] being the world's numberone producer of this species [1].

Recently, the vegetable-based protein ingredients have been used because of the difficulty in providing fish meal that is no longer economically feasible and not sustainable [3]. The use of fish meal in feeds also increases the accumulation of nitrogen and phosphorus in aquatic environments [4].
The most commonly used vegetable-based ingredients are soy products and meal, sunflower oil and meal, cottonseed oil and meal, rapeseed oil meal, corn gluten meal, canola meal, peanut meal, and oatmeal [5]. Safflower (Carthamus tinctorius) is an oil seed plant that needs little water and can live in more arid conditions than soybean and sunflower. It can also be considered a sustainable plant due to its ease of supply and oil seed [6]. Safflower meal can also be used proportionally instead of soybean meal or other protein sources because of its protein content (about 20-25\%) [7]. Previous studies report that safflower meal can be safely used as a protein source in rainbow trout feeds up to $20 \%$ in fish experimental diets $[8,9]$.

Antinutrients in plant compounds used in fish feed like phytate have negative impacts on feed intake, digestion, and 
nutrient absorption [10], while some enzyme supplements increased digestibility and reduced negative effects of antinutritional factors [11]. According to Francis et al. [10], ingredients containing phytate have negative effects on growth, particularly on species of carp, tilapia, and trout. Addition of the phytase enzyme in fish with limited intestinal phytase can combine with amino acids and proteins, improve the digestion of these complex structures like phytate in fish, and also reduce the negative effects of phytate [12]. In vitro studies demonstrate that phytate-protein structures are not soluble and are less affected by proteolytic enzymes [13]. Because the discharge of unavailable phosphorus and the phytate-protein complex from aquaculture environments causes increases on growth of algae and phytoplankton, it leads to a reduction in the amount of dissolved oxygen and pollution [14]. Phytase also led to increases on the availability of trace elements found in feeds $[15,16]$. Another positive effect of adding phytase to feeds is the contribution of converting phytate, an antinutritional factor with limited digestion in monogastric animals, to absorbable phosphorus [17]. Another advantage is that it increases the bioavailability of nutritional amino acids and energy [18]. Use of microbial phytase in fish feed can enhance the bioavailability of phytate-bound $\mathrm{P}$ and nitrogen, and thus, less $\mathrm{P}$ is discharged into the aquatic environment $[14,15]$. Therefore, phytase is increasingly considered as the dispensable additive for a cost-effective and environmental friendly fish-feed formula [15]. Commercial phytase has been used in animal feed for more than 20 years, especially in feeds for pork, poultry, and, more recently, fish and shrimp, in order to reduce environmental impact and the accumulation of waste in farms [17].

Several studies have been conducted on the effects of vegetable-based ingredients on rainbow trout feed [19-22] Enzymes were also added to rainbow trout feeds using vegetable-based ingredients and using the microbial phytase enzyme [23-27]. Although the effects of the safflower meal on the rainbow trout have been studied $[8,9]$, no studies focusing on replacement of soybean meal with safflower meal and its effect when used together with the phytase enzyme are available. Sardar et al. [28] Found that phytase was effective in releasing most of the phytate-bound proteins, amino acids, and minerals for optimum utilization and performance and had no negative effects on serum biological parameters.

This study aimed to investigate the effects of the sustained use of safflower meal, instead of soybean meal, together with the microbial phytase enzyme on the reduction of antinutritional factors in feeds, increased digestibility of feeds, growth performance, serum biochemistry, and feed conversion of rainbow trout.

\section{Materials and Methods}

2.1. Preparation of Experiment Feeds. Five different isonitrogenous (44\%) and isocaloric (23 kJ) experimental feeds were formulated to meet the nutritional needs of rainbow trout. The feed experiment included a control feed with no safflower meal or phytase (C), a $10 \%$ safflower meal instead of soybean meal (SFM10), a $20 \%$ safflower meal instead of the soybean meal (SFM20), a safflower meal instead of the $10 \%$ soybean meal and $1000 \mathrm{U} / \mathrm{kg}$ of the phytase enzyme (SFM10 $\left.\pm \mathrm{P}_{1000}\right)$, and a $20 \%$ of safflower meal instead of the soybean meal and $2000 \mathrm{U} / \mathrm{kg}$ of the phytase enzyme $\left(\mathrm{SFM} 20 \pm \mathrm{P}_{2000}\right)$. After preparation of the trial feeds, phytase activity was determined using Na-phytate as the substrate. Phytase activities were found, $980 \mathrm{U} / \mathrm{kg}$ in the $\mathrm{SFM} 10 \pm \mathrm{P}_{1000}$ group and $1940 \mathrm{U} / \mathrm{kg}$ in the $\mathrm{SFM} 20 \pm \mathrm{P}_{2000}$ group. Fish meal, soybean meal, wheat flour, wheat gluten, fish oil, safflower meal, vitamin and mineral premixes, and phytase enzymes used in the experiment feeds are reported in Table 1. Essential amino acid compositions of trial feeds are given in Table 2.

Dry ingredients were mixed together based on the given diets. Feeds containing the phytase enzyme were added after being weighed and homogenized for 16 minutes. Fish oil and water were added to the mixture to a pulp that was converted to $2 \mathrm{~mm}$ diameter pellet after being passed through a pelletizer. The pellets were prepared using a cooled (about $70^{\circ} \mathrm{C}$ ) feed making machine. Prepared feeds were crumbled into a dried material for three days maintained at $4^{\circ} \mathrm{C}$ until used.

2.2. Experimental Layout. The experimental rainbow trout were obtained from a private company located in Seydikemer, Muğla, Turkey. The feeding experiment was carried out in an open-circuit system (15 plastic tanks with a volume of 270 liters) established at the aquaculture unit of Muğla Sitkı Koçman University, Ortaca Vocational School. In the experiment, 15 fish with an average weight of $12.57 \pm 3.05 \mathrm{~g}$ were used for each tank after being starved for one day. During the experiment, the fish were fed 3 times a day (09: $00,12: 30$, and 17:00) to satiation for 60 days. Uneaten feed and feces were siphoned daily.

2.3. Sampling and Analytical Methods. Five fish from each group were randomly sampled and stored at $-20^{\circ} \mathrm{C}$ until used for analysis. Fish feces were collected and stored at $-20^{\circ} \mathrm{C}$ daily starting from the $30^{\text {th }}$ day of the experiment to determine feed digestibility.

Crude protein, crude lipid, crude ash, and moisture of feed ingredients, experimental feeds, fish feces, and sampled fish were determined by standard methods [30] at the beginning and end of the experiment.

2.4. Analysis of Water Quality Parameters. Dissolved oxygen in water, temperature, and $\mathrm{pH}$ were measured daily using the Hach-Lange brand multiparameter device. The $\mathrm{N}-\mathrm{NO}_{2}$ and $\mathrm{N}-\mathrm{NO}_{3}$ content of water was measured weekly by means of Noratex brand test kits. The mean values were as follows: $19.7^{\circ} \mathrm{C} \pm 2^{\circ} \mathrm{C}$ mean water temperature, $8.9 \pm 0.5 \mathrm{mg} / \mathrm{L}$ dissolved oxygen, $8.01 \pm 0.3 \mathrm{pH}, 0.1 \mathrm{ppm} \mathrm{N}-\mathrm{NO}_{2}$, and $5 \mathrm{ppm}$ $\mathrm{N}-\mathrm{NO}_{3}$ nitrogen. 
TABLE 1: Nutritional and chemical proximate composition of experiment feeds.

\begin{tabular}{|c|c|c|c|c|c|}
\hline Ingredients & Control & SFM10 & SFM20 & $\mathrm{SFM} 10 \pm \mathrm{P}_{1000}$ & $\mathrm{SFM} 20 \pm \mathrm{P}_{2000}$ \\
\hline \multicolumn{6}{|l|}{ Formulation ( $\mathrm{g} \mathrm{kg}^{-1}$ as fed) } \\
\hline Fish meal & 435 & 435 & 445 & 435 & 445 \\
\hline Soybean meal & 295 & 270 & 240 & 270 & 240 \\
\hline Wheat meal & 135 & 120 & 110 & 120 & 110 \\
\hline Fish oil & 100 & 100 & 100 & 100 & 100 \\
\hline Safflower meal & - & 30 & 60 & 30 & 60 \\
\hline Wheat gluten & 20 & 30 & 30 & 30 & 30 \\
\hline Vitamin-mineral mix & 5 & 5 & 5 & 5 & 5 \\
\hline Antioxidant & 10 & 10 & 10 & 10 & 10 \\
\hline Phytase & - & - & - & $1000 \mathrm{IU} / \mathrm{kg}$ & $2000 \mathrm{IU} / \mathrm{kg}$ \\
\hline \multicolumn{6}{|l|}{ Composition } \\
\hline Dry matter & $91.57 \pm 0.6^{\mathrm{a}}$ & $91.46 \pm 0.83^{\mathrm{a}}$ & $91.64 \pm 0.62^{\mathrm{a}}$ & $91.33 \pm 0.75^{\mathrm{a}}$ & $91.78 \pm 0.43^{\mathrm{a}}$ \\
\hline Crude protein & $44.39 \pm 0.32^{\mathrm{a}}$ & $44.35 \pm 0.21^{\mathrm{a}}$ & $44.10 \pm 0.56^{\mathrm{a}}$ & $44.33 \pm 0.13^{\mathrm{a}}$ & $44.13 \pm 0.42^{\mathrm{a}}$ \\
\hline Crude lipid & $12.96 \pm 0.03^{\mathrm{a}}$ & $12.55 \pm 0.4^{\mathrm{a}}$ & $13.42 \pm 0.28^{\mathrm{a}}$ & $12.48 \pm 0.36^{\mathrm{a}}$ & $13.50 \pm 0.27^{\mathrm{a}}$ \\
\hline Crude ash & $10.29 \pm 0.24^{\mathrm{a}}$ & $10.28 \pm 0.23^{\mathrm{a}}$ & $10.32 \pm 0.28^{\mathrm{a}}$ & $10.22 \pm 0.21^{\mathrm{a}}$ & $10.38 \pm 0.28^{\mathrm{a}}$ \\
\hline $\mathrm{NFE}^{1}$ & 32.36 & 32.41 & 32.16 & 32.97 & 31.99 \\
\hline Gross energy $\left(\mathrm{kJkg}^{-1}\right)^{2}$ & 23.10 & 22.82 & 23.08 & 22.87 & 23.06 \\
\hline
\end{tabular}

Each value refers to mean \pm standard deviation. Values expressed in different exponents in the same column are statistically different from each other $(p<0.05) .{ }^{1}$ Nitrogen-free extracts $(\mathrm{NFE})=$ matter $-\left(\right.$ crude lipid + crude ash + crude protein). ${ }^{2}$ Energy calculated according to $23.6 \mathrm{~kJ} \mathrm{~g}^{-1} \mathrm{protein}, 39.5 \mathrm{~kJ} \mathrm{~g}^{-1}$ lipid, and $17.0 \mathrm{~kJ} \mathrm{~g}^{-1} \mathrm{NFE}$.

TABLE 2: Essential amino acid composition of experiment feeds.

\begin{tabular}{|c|c|c|c|c|c|c|}
\hline Essential A.A. & Trout & Control & SFM10 & SFM20 & $\mathrm{SFM} 10 \pm \mathrm{P}_{1000}$ & $\mathrm{SFM} 20 \pm \mathrm{P}_{2000}$ \\
\hline Arginine & 2.0 & 2.94 & 2.94 & 2.93 & 2.94 & 2.93 \\
\hline Histidine & 0.7 & 0.99 & 1 & 0.98 & 1 & 0.98 \\
\hline Valine & 1.3 & 2.03 & 2.04 & 2.03 & 2.04 & 2.03 \\
\hline Isoleucine & 0.8 & 1.86 & 1.87 & 1.85 & 1.87 & 1.85 \\
\hline Phenylalanine & 1.86 & 1.82 & 1.82 & 1.81 & 1.82 & 1.81 \\
\hline Threonine & 1.8 & 1.67 & 1.66 & 1.63 & 1.66 & 1.63 \\
\hline Methionine & 1.45 & 0.93 & 0.94 & 0.94 & 0.94 & 0.94 \\
\hline Tryptophan & 1.2 & 0.46 & 0.466 & 0.57 & 0.466 & 0.57 \\
\hline Lysine & 1.8 & 2.91 & 2.89 & 2.88 & 2.89 & 2.88 \\
\hline Leucine & 1.4 & 3.2 & 3.21 & 3.08 & 3.21 & 3.08 \\
\hline
\end{tabular}

Data on proximate composition and amino acid contents of fishmeal, soybean meal, wheat gluten meal, wheat meal, and safflower meal are from [29] and calculated to dry matter. Amino acid amount needed for rainbow feed is given as a percentage [4].

2.5. Calculation of Growth Parameters. Growth parameters were calculated with the following equations:

Weight gain $(\%)=[$ final weight $(\mathrm{g})-$ initial weight $(\mathrm{g})] /$ initial weight $(\mathrm{g})] \times 100$

Specific growth rate $(\%$ day -1$)=[\operatorname{Ln}($ final average weight $(\mathrm{g}))-\operatorname{Ln}($ initial average weight $(\mathrm{g}))$ ]/ trial days $\times 100$

Feed conversion rate $=$ total feed intake $(g) /$ weight gain (g) + weights of dead fish (g)

The nutrient digestibility rate was calculated, and the amount of acid insoluble ash was used as a marker.

Digestibility rate $(\%)=100[100 X($ marker in feed $(\%) /$ marker in feces (\%) $\cdot X$ nutrient in feces (\%)/ nutrient in $\operatorname{diet}(\%)]$

Phosphorus contents of feed and feces were measured by using Optima 7000 DV model inductively coupled plasma atomic emission spectrometry (ICP-AES).
2.6. Blood Sampling and Analyses of Haematological and Serum Biochemical Parameters. At the end of the feeding experiment, blood was sampled from 75 fish (5 fish per tanks) per group anaesthetized using clove oil $(20 \mathrm{mg} / \mathrm{L})$. Blood was taken in serum tubes (MiniCollect ${ }^{\circledR}$ tube) and centrifuged at $5,000 \mathrm{~g}$ for $10 \mathrm{~min}$ [31]. Obtained serum samples were stored at $-80^{\circ} \mathrm{C}$ for further biochemical and immunological analysis. For the determination of biochemical parameters, such as GLU (glucose), TPROT (total protein), CHOL (cholesterol), ALP (alkaline phosphatase), and GOT (glutamic-oxaloacetic transaminase), commercial test kits (Bioanalytic Diagnostic Industry, Germany) were used via a spectrophotometer (Optizen POP UV/VIS) [32].

2.7. Statistical Analyses. Statistical differences among the experiment groups were tested by one-way ANOVA followed by post hoc Tukey's test $(p<0.05)$ by using SPSS for Windows 22.0 program. 


\section{Results}

3.1. Growth Parameters. The difference between the groups was not significant in terms of mean individual live weights $(p>0.05)$. Table 3 reports the values for average weight gain, specific growth rate, and survival rate obtained at the end of the experiment. The statistical differences between the SFM20 group and the SFM $20 \pm \mathrm{P}_{2000}$ group in terms of weight gain and specific growth rates were significant $(p<0.05)$, but the difference between these groups was not significant.

3.2. Findings Related to Feed Conversion. In Table 3, the feed conversion ratio is reported. Only differences between the SFM 20 group and the SFM $20 \pm \mathrm{P}_{2000}$ group were statistically significant; it was thought that the usage of $2000 \mathrm{U} / \mathrm{kg}$ of the phytase enzyme was effective in decreasing the feed conversion ratio in both groups using $20 \%$ safflower meal instead of soybean.

3.3. Findings Related to Digestibility Rate. Table 4 provides the rates of apparent digestibility of the feeds. There was no significant difference among the total rates of digestibility $(p<0.05)$. The phosphorus digestibility of the SFM20 $\pm \mathrm{P}_{2000}$ group was significant compared with the other groups $(p<0.05)$.

3.4. Total Phosphorus Amount in Feed and Feces. The results obtained in $\mathrm{mg} / \mathrm{kg}$ are converted to percentages and given in Table 5. It was found that the total amount of phosphorus in the feeds was the lowest in the control group and was statistically significant from other groups $(p<0.05)$. For the amount of phosphorus in the feces, the differences between the SFM10 and the control groups and between the SFM10 and SFM20 $\pm \mathrm{P}_{2000}$ groups were found to be statistically significant $(p<0.05)$.

3.5. Biochemical Composition of Fish and Feces. Table 5 provides the biochemical analysis of the fish and feces values. Difference in the amount of crude protein in the feces in the control group was statistically significant compared with the other groups $(p<0.05)$. The statistical difference between the control group and the SFM $20 \pm \mathrm{P}_{2000}$ group in all biochemical values was not significant, but their values were significantly higher than the other groups $(p<0.05)$.

3.6. Serum Biological Parameters. The results of serum biochemistry are summarized in Table 6. ALP, LDH, TPROT, and triglycerides levels were not statistically different among the feeding groups. ALT and AST in the SFM10 group were statistically different from the control, SFM10 $\pm \mathrm{P}_{1000}$, and SFM20 $\pm \mathrm{P}_{2000}$ groups $(p<0.05)$. Glucose in SFM10 $\pm \mathrm{P}_{1000}$ was statistically different from the control and SFM10 groups. Albumin levels were the highest in phytase and SFM $20 \pm \mathrm{P}_{2000}$ groups and statistically different from nonphytase groups $(p<0.05)$. The level of cholesterol was statistically significantly higher in the SFM10 $\pm \mathrm{P}_{1000}$ group than in SFM10 and SFM20 groups.

\section{Discussion}

In this study, the use of safflower meal instead of soybean meal and the supplementation of the phytase enzyme did not have any adverse effect on the parameters of growth, feed conversion, and serum biochemistry. Moreover, the use of phytase at doses of $1000 \mathrm{U} / \mathrm{kg}$ and $2000 \mathrm{U} / \mathrm{kg}$ reduced fecal phosphorus emission and improved growth parameters. The best-performing group in terms of the parameters of growth and feed was the group using 20\% safflower meal instead of soybean meal together with $2000 \mathrm{U} / \mathrm{kg}$ phytase. Similar results were found by Tiril and Kerim [9], who used safflower meal up to $20 \%$, and by [11] that using rainbow trout using of similar enzyme ratio of our study found $87.0 \pm 1.5 \mathrm{~g}$ mean weight. Castro et al. [33] observed that the values of $127.07 \pm 7.73 \%$ obtained from the SFM $20 \pm$ P2000 group with an average weight of $4.12 \pm 0.7 \mathrm{~g}$ exhibited a similar increase in live weight gain (131\%) for the group containing $100 \%$ soybean meal and the phytase enzyme on the rainbow trout. The specific growth rate was $0.96-1.36 \%$ in the study, and it was similar to the values of $0.84 \%-1.33 \%$ found by Jalili et al. [34] in the rainbow trout trial. Dalsgaard et al. [25] found that specific growth rates ranged from $1.7 \%$ to $1.9 \%$. The higher values than this study can be due to specific physical and/or environmental conditions and to different biochemical contents of the feed ingredients. Yiğit et al. [27] reported the specific growth rate values of $0.91-0.97 \%$, values lower than those obtained in the present study. These differences could be due to the enzymes used (beta-mannanase and galactosidase) or to differences in the protein contents in the feeds.

Addition of the phytase enzyme on feed conversion did not have any adverse effects but, conversely, led to improvements when compared with the control groups. Adding the phytase enzyme to rainbow trout feeds containing canola meal in Yigit and Keser's study [22] reported a feed conversion ratio of $1.19 \pm 0.01$ in the phytase group. Yigit and Keser's study was consistent with the current study in terms of fish weights and experiment duration, but there were differences in terms of the control group. Yigit et al. [27] tried using the phytase enzyme at two different doses made with soybean-based feeds in their study. At the end of the experiment, they found that the feed conversion ratios of $1.61 \pm 0.03$ and $1.62 \pm 0.06$ were higher than this study. These differences can be due to fish size, enzyme source, and different protein sources in the feeds. Haghbayan and Shamsaie Mehrgan [20] found feed conversion ratios of $1.18 \%$ and $1.11 \%$ in the groups supplemented with the enzyme and $25 \%$ and $50 \%$ soybean meal, respectively, in their experiment. These values were consistent with the present study.

The addition of the enzyme increased phosphorus digestibility in cold-water fish fed with previously studied vegetable-based feeds. The most effective dosage range for phytase was determined to be $500-1000 \mathrm{U} / \mathrm{kg}$. According to Lemos and Tacon [17], $2000 \mathrm{U} / \mathrm{kg}$ doses provided significant results depending on species and temperature. In unison 
TABLE 3: Growth performance and feed conversion rate analyses in the experiment fish.

\begin{tabular}{|c|c|c|c|c|c|}
\hline Parameters & Control & SFM10 & SFM20 & $S F M 10 \pm P_{1000}$ & SFM20 $\pm P_{2000}$ \\
\hline Initial weight $(\mathrm{g})$ & $12.78 \pm 3.16$ & $12.72 \pm 2.85$ & $12.54 \pm 3.01$ & $12.37 \pm 2.91$ & $12.50 \pm 3.25$ \\
\hline Final weight (g) & $26.76 \pm 7.43^{\mathrm{ab}}$ & $24.47 \pm 8.76^{\mathrm{ab}}$ & $22.47 \pm 11.24^{\mathrm{a}}$ & $25.65 \pm 3.25^{\mathrm{ab}}$ & $28.39 \pm 4.15^{\mathrm{b}}$ \\
\hline Weight gain (\%) & $109.15 \pm 17.71^{\mathrm{ab}}$ & $92.53 \pm 11.18^{\mathrm{ab}}$ & $78.97 \pm 7.12^{\mathrm{a}}$ & $107.26 \pm 10.61^{\mathrm{ab}}$ & $127.07 \pm 7.73^{\mathrm{b}}$ \\
\hline SGR $(\%)$ & $1.22 \pm 0.14^{\mathrm{ab}}$ & $1.08 \pm 0.09^{\mathrm{ab}}$ & $0.96 \pm 0.06^{\mathrm{a}}$ & $1.21 \pm 0.08^{\mathrm{ab}}$ & $1.36 \pm 0.05^{\mathrm{b}}$ \\
\hline Feed conversion rate & $1.27 \pm 0.09^{\mathrm{ab}}$ & $1.37 \pm 0.11^{\mathrm{ab}}$ & $1.57 \pm 0.03^{\mathrm{b}}$ & $1.35 \pm 0.14^{\mathrm{ab}}$ & $1.13 \pm 0.020^{\mathrm{a}}$ \\
\hline Survival rate (\%) & $86.66 \pm 9.42$ & $97.77 \pm 3.14$ & $100.0 \pm 0.00$ & $100.0 \pm 0.00$ & $97.77 \pm 3.14$ \\
\hline
\end{tabular}

Each value refers to mean \pm standard deviation. Values expressed in different exponents in the same row are statistically different from each other $(p<0.05)$.

TAвLE 4: Parameters related to feed digestibility rates of fish in the experiment.

\begin{tabular}{|c|c|c|c|c|c|}
\hline Parameters & Control & SFM10 & SFM20 & $\mathrm{SFM} 10 \pm \mathrm{P}_{1000}$ & $\mathrm{SFM} 20 \pm \mathrm{P}_{2000}$ \\
\hline Total digestibility rate (\%) & $72.45 \pm 0.40$ & $71.13 \pm 0.80$ & $71.33 \pm 0.33$ & $72.03 \pm 0.60$ & $72.73 \pm 0.62$ \\
\hline Protein digestibility rate (\%) & $93.75 \pm 0.16^{\mathrm{a}}$ & $94.33 \pm 0.26^{\mathrm{b}}$ & $94.37 \pm 0.10^{\mathrm{b}}$ & $94.31 \pm 0.10^{\mathrm{b}}$ & $94.67 \pm 0.13^{\mathrm{b}}$ \\
\hline Lipid digestibility rate (\%) & $97.83 \pm 0.08^{c}$ & $96.53 \pm 0.40^{\mathrm{b}}$ & $95.25 \pm 0.61^{\mathrm{a}}$ & $97.46 \pm 0.33^{b c}$ & $96.34 \pm 0.27^{\mathrm{ab}}$ \\
\hline Phosphorus digestibility rate (\%) & $79.26 \pm 0.21^{\mathrm{b}}$ & $77.10 \pm 0.32^{\mathrm{a}}$ & $79.03 \pm 0.41^{\mathrm{b}}$ & $81.43 \pm 0.63^{\mathrm{c}}$ & $84.09 \pm 0.33^{\mathrm{d}}$ \\
\hline
\end{tabular}

Each value refers to mean \pm standard deviation. Values expressed in different exponents in the same row are statistically different from each other $(p<0.05)$.

TABLE 5: Biochemical composition of fish and feces.

\begin{tabular}{|c|c|c|c|c|c|c|}
\hline Parameters & Initial & Control & SFM10 & SFM20 & $\mathrm{SFM} 10 \pm \mathrm{P}_{1000}$ & SFM20 $\pm P_{2000}$ \\
\hline Crude protein (\%) & $13.40 \pm 0.07^{\mathrm{a}}$ & $20.94 \pm 0.14^{\mathrm{d}}$ & $16.49 \pm 0.33^{\mathrm{b}}$ & $18.95 \pm 0.34^{\mathrm{c}}$ & $19.59 \pm 0.74^{\mathrm{c}}$ & $20.96 \pm 0.24^{\mathrm{d}}$ \\
\hline Crude lipid (\%) & $3.27 \pm 0.21^{\mathrm{a}}$ & $3.37 \pm 0.13^{\mathrm{a}}$ & $3.21 \pm 0.43^{\mathrm{a}}$ & $3.69 \pm 0.23^{\mathrm{a}}$ & $4.04 \pm 0.50^{\mathrm{a}}$ & $4.46 \pm 0.90^{\mathrm{a}}$ \\
\hline Crude ash $(\%)$ & $1.88 \pm 0.02^{\mathrm{b}}$ & $1.79 \pm 0.07^{\mathrm{b}}$ & $1.63 \pm 0.02^{\mathrm{a}}$ & $1.76 \pm 0.04^{\mathrm{ab}}$ & $1.8 \pm 0.03^{\mathrm{b}}$ & $1.87 \pm 0.04^{\mathrm{b}}$ \\
\hline Moisture (\%) & $77.79 \pm 0.17^{\mathrm{c}}$ & $72.83 \pm 0.10^{\mathrm{a}}$ & $75.10 \pm 0.24^{\mathrm{b}}$ & $74.84 \pm 0.24^{\mathrm{b}}$ & $74.54 \pm 0.44^{\mathrm{b}}$ & $72.96 \pm 0.48^{\mathrm{a}}$ \\
\hline Dry matter (\%) & $22.21 \pm 0.16^{\mathrm{a}}$ & $27.17 \pm 0.08^{c}$ & $24.90 \pm 0.24^{\mathrm{b}}$ & $25.16 \pm 0.25^{\mathrm{b}}$ & $25.46 \pm 0.36^{\mathrm{b}}$ & $27.04 \pm 0.11^{\mathrm{c}}$ \\
\hline Phosphorus in feed (\%) & - & $1.01 \pm 0.04^{\mathrm{a}}$ & $1.22 \pm 0.06^{\mathrm{b}}$ & $1.18 \pm 0.05^{\mathrm{b}}$ & $1.19 \pm 0.01^{\mathrm{b}}$ & $1.20 \pm 0.02^{\mathrm{b}}$ \\
\hline Phosphorus in feces (\%) & - & $0.76 \pm 0.04^{\mathrm{a}}$ & $0.97 \pm 0.02^{\mathrm{b}}$ & $0.83 \pm 0.05^{\mathrm{ab}}$ & $0.79 \pm 0.05^{\mathrm{ab}}$ & $0.70 \pm 0.08^{\mathrm{a}}$ \\
\hline Crude protein in feces (\%) & - & $10.07 \pm 0.31^{\mathrm{b}}$ & $8.72 \pm 0.01^{\mathrm{a}}$ & $8.66 \pm 0.10^{\mathrm{a}}$ & $9.01 \pm 0.04^{\mathrm{a}}$ & $8.62 \pm 0.11^{\mathrm{a}}$ \\
\hline Crude lipid in feces (\%) & - & $1.02 \pm 0.00^{\mathrm{a}}$ & $1.51 \pm 0.00^{\mathrm{a}}$ & $2.22 \pm 0.00^{\mathrm{b}}$ & $1.13 \pm 0.06^{\mathrm{a}}$ & $1.81 \pm 0.44^{\mathrm{b}}$ \\
\hline
\end{tabular}

Each value refers to mean \pm standard deviation. Values expressed in different exponents in the same row are statistically different from each other $(p<0.05)$.

TABLE 6: Serum biological parameters.

\begin{tabular}{lccccc}
\hline Serum biochem. & Control & SFM10 & SFM20 & SFM10 $\pm P_{1000}$ & SFM20 $\pm P_{2000}$ \\
\hline ALT & $9.84 \pm 1.57$ & $5.55 \pm 2.44$ & $8.22 \pm 2.53$ & $9.68 \pm 3.29$ & $9.31 \pm 2.09$ \\
AST & $75.64 \pm 24.32$ & $51.59 \pm 29.65$ & $73.86 \pm 47.11$ & $107.38 \pm 40.27$ & $106.28 \pm 27.92$ \\
ALP & $236.28 \pm 58.29$ & $283.55 \pm 106.70$ & $208.63 \pm 67.65$ & $269.61 \pm 123.94$ & $308.84 \pm 98.37$ \\
LDH & $927.39 \pm 130.80$ & $1052.84 \pm 339.29$ & $733.55 \pm 298.22$ & $967 \pm 263.12$ & $923.31 \pm 321.54$ \\
Glucose & $51.97 \pm 28.93^{\mathrm{a}}$ & $69.84 \pm 21.25^{\mathrm{a}}$ & $102.44^{\mathrm{b}} \pm 30.07^{\mathrm{b}}$ & $107.77 \pm 34.08^{\mathrm{b}}$ & $97.97 \pm 19.27^{\mathrm{b}}$ \\
TPROT & $8.93 \pm 1.24$ & $7.26 \pm 0.43$ & $7.74 \pm 1.49$ & $8.6 \pm 1.54$ & $8.31 \pm 1.28$ \\
ALB & $0.65 \pm 0.12$ & $0.56 \pm 0.13$ & $0.56 \pm 0.20$ & $0.73 \pm 0.20$ & $0.89 \pm 0.10$ \\
Triglycerides & $91.92 \pm 25.88$ & $93.85 \pm 17.67$ & $84.88 \pm 26.74$ & $105.36 \pm 20.68$ & $100.98 \pm 20.49$ \\
CHOL & $232.47 \pm 36.78^{\mathrm{a}}$ & $213.65 \pm 31.31^{\mathrm{a}}$ & $207.64 \pm 43.43^{\mathrm{a}}$ & $314.62 \pm 117.71^{\mathrm{b}}$ & $245.84 \pm 31.93^{\mathrm{ab}}$ \\
\hline
\end{tabular}

Each value refers to mean \pm standard deviation. Values expressed in different exponents in the same row are statistically different from each other $(p<0.05)$.

with this, $1000 \mathrm{U} / \mathrm{kg}$ and $2000 \mathrm{U} / \mathrm{kg}$ phytase enzymes were added in our study, and it is possible to discuss the positive effects of both proportions on digestibility in the findings.

The protein and lipid digestibility rates in this study were acceptable when compared to other studies in which the enzyme was added to the rainbow trout feeds that contain vegetable-based ingredients. Wang et al. [23] studied the effects of rainbow trout feeds containing soybean meal, which are sprayed and supplemented with pretreated phytase, and their protein and lipid digestibility rates were similar to those in this study. Dalsgaard et al. [25] found the average protein digestibility rate to be $94 \%$ and average lipid digestibility rate to be $93-94 \%$ with rainbow trout feeds containing $1400 \mathrm{U} / \mathrm{kg}$ phytase. These values were very similar to the values in groups supplemented with the phytase enzyme in this study, and the similarity in the ratios 
of phytase addition was notable. Ustaoglu Tiril and Kerim [9] found a protein digestibility rate between $83.54 \%$ and $85.44 \%$, which was lower than the values in this study. However, the lipid digestibility rate was between $93.02 \%$ and $95.05 \%$, in accordance with our study. According to Vandenberg et al. [24], in the group supplemented with $2000 \mathrm{U} /$ $\mathrm{kg}$ and $4000 \mathrm{U} / \mathrm{kg}$, they found protein digestibility ratio to be, respectively, $91.3 \%$ and $93.3 \%$. These values were very similar to the values in this study, and it can be deduced that the increased enzyme ratio in the feeds might have had an effect on protein digestibility. Morales et al. [21] reported the protein digestibility rate of $92.0 \%$ in the group supplemented with $4000 \mathrm{U} / \mathrm{kg}$ phytase, and this value was relatively low compared to the values in this study. This can probably be due to the differences in the initial weights of the fish, although the experimental periods and phytase rates were similar. Yigit et al. [27] found that the lipid digestibility rate was between $80.00 \%$ and $89.00 \%$. These values were lower compared with this study, and the differences may be due to different uses of enzymes and ingredient usage rates in the experiments. It can be seen in this study as well as other studies that adding enzymes to feeds may increase protein and lipid digestibility.

Vandenberg et al. [24] calculated the phosphorus digestibility rate to be $75.2 \%$ in the group supplemented with $4000 \mathrm{U} / \mathrm{kg}$ phytase enzyme. It was also predicted that the cause of the lower values from the phytase groups in our study might be the sources of the enzymes as well as differences in ingredients and ratios used. Diler et al. [11] found the phosphorus digestibility rate to be $74.99-86.58 \%$. These values were similar to those in this study, although the values between $73.2 \%$ and $75.7 \%$ were lower than those in this study. The differences can be due to different enzyme usage. According to Verlhac-Trichet et al. [26], the phosphorus digestibility rate was $70.6 \pm 2.5 \%$ in the study of supplemented $2000 \mathrm{U} / \mathrm{kg}$ microbial phytase. Although this was lower than the value in this study, it was important in terms of feeds supplemented with phytase increasing the phosphorus digestibility rate. In this study, adding the phytase enzyme to rainbow trout feeds increased the total phosphorus digestibility in phytase-supplemented groups.

By applying phytase in plant protein-based fish diets, the digestibility of phytate-phosphorus will be increased [28]. This situation has been seen in previous studies by Diler et al. and Dalsgaard et al. $[11,25]$ as well as in this study that adding enzyme to rainbow trout feed reduced total phosphorus in feces. However, the values found in those research studies were higher than those in this study maybe due to the different phosphorus contents in the ingredients used. The addition of the phytase enzyme and safflower meal to rainbow trout feeds did not have any adverse effects on crude protein, crude lipid, and crude ash values, as observed in similar studies. The rates of crude protein and crude lipid in this study were $16.20 \%-20.96 \%$ and $3.21 \%-4.46 \%$, respectively, similar to other studies of rainbow trout $[9,19,20,35]$ The results regarding crude ash in this study were similar to earlier studies of rainbow trout $[27,35]$.

ALP, LDH, TPROT, and triglyceride levels were not statistically different in feeding groups. The authors of [36] did not find any effects of phytase enzyme on ALP, LDH, and TPROT. Shehab et al. [37] also did not find any statistical difference on triglycerides and total protein levels. Sardar et al. [28] found the effects of microbial phytase on glucose levels on Cyprinus carpio. $1000 \mathrm{IU} / \mathrm{kg}$ or $2000 \mathrm{IU} / \mathrm{kg}$ phytase in diet did not any negative effect on haemato-biochemical status of fish which might be due to proper utilization of dietary nutrients in presence of supplemental phytase. Present results were in agreement with the findings of Sardar et al. [28] in carps. ALB and AST levels were not affected by the phytase enzyme in the study of Liu et al. [38], and also, triglycerides were not affected on the grass carp trial.

\section{Conclusion}

As a conclusion, this study reported that use of safflower meal up to $10 \%$ instead of soybean meal in the rainbow trout with average weights of $12-13 \mathrm{~g}$ has a positive effect on growth performance, body composition, and feed conversion. In addition, the use of microbial phytase at doses of $1000 \mathrm{U} / \mathrm{kg}$ and $2000 \mathrm{U} / \mathrm{kg}$ reduced phosphorus release and improved growth parameters of fish. Phytase enzyme with safflower meal did not bring any negative effect on serum biochemistry in the rainbow trout. The best-performing group in terms of the parameters of growth and feed was the control group and the group using $20 \%$ safflower meal instead of soybean meal together with $2000 \mathrm{U} / \mathrm{kg}$ phytase. Supplementing enzymes in rainbow trout feed reduced total phosphorus in feces. Future studies are encouraged to use different enzymes with different safflower meal ratios to compare the effects of the phytase enzyme and other enzymes on other cultured fish in addition to rainbow trout.

\section{Data Availability}

No data were used to support this study.

\section{Disclosure}

This study was summarized from the master thesis of Ismail Berat Cantas.

\section{Conflicts of Interest}

The authors declare that there are no conflicts of interest regarding the publication of this paper.

\section{Authors' Contributions}

Both authors contributed to each stage of the study.

\section{Acknowledgments}

This study was supported by Instructor Training Program which was found by the Turkish Council of Higher Education. 


\section{References}

[1] FAO, Global Aquaculture Production, FAO, Rome, Italy, 2018, http://www.fao.org/fishery/statistics/global-aquacultureproduction/query/en.

[2] TÜIK, Su Ürünleri Istatistikleri (Fisheries Statistics), TÜIK, Ankara, Turkey, 2019, http://www.tuik.gov.tr.turkish. statistical.institute.

[3] K. Murashita, H. Fukada, N. Takahashı et al., "Effect of feed ingredients on digestive enzyme secretion in fish," vol. 40, pp. 69-74, Bulletin Fish Research Agency, 2015.

[4] R. W. Hardy, Nutrient Requirements and Feeding of Finfish for Aquaculture, C. D. Webster and C. E. Lim, Eds., CABI Publishing, Wallingford, Oxfordshire, England, 2002.

[5] A. Ö. Hunt, F. Özkan, and T. Altun, "Balık yemlerinde beslenmeyi sınırlandırıcı maddeler ve etkileri. (Nutrition limiting agents and their effects in fish feeds)," Turkish Journal of Sucul Yaşam, vol. 5, no. 8, pp. 634-642, 2007.

[6] J. Gilbert, "International safflower production an overview," in Proceedings of the 7th International Safflower Conference, Australian Oilseeds Federation, Wagga Wagga, NSW, Australia, November 2008.

[7] E. Yenice and M. Gültekin, "Aspir küspesinin kanatlı hayvanların yemlerinde kullanım olanakları (possibility of using safflower meal in poultry feed)," Yem Magazin, vol. 81, pp. 33-39, 2018.

[8] S. Ustaoğlu Tiril, S. Dernekbasi, I. Karayucel, M. Kerim, and A. P. Akyuz, "Effects of canola and safflower oil supplementation in diets on growth performance and fatty acid composition of Russian sturgeon (Acipencer gueldenstaedtii brandt, 1833)," The Israeli Journal of Aquaculture-Bamidgeh, vol. 68, pp. 1222-1234, 2016.

[9] S. Ustaoglu Tiril and M. Kerim, "Evaluation of safflower meal as a protein source in diets of rainbow trout [Oncorhynchus mykiss, Walbaum, 1792)]," Journal of Applied Ichthyology, vol. 31, no. 5, pp. 895-899, 2015.

[10] G. Francis, H. P. S. Makkar, and K. Becker, "Anti-nutritional factors present in plant-derived alternate fish feed ingredients and their effects in fish," Aquaculture, vol. 199, no. 3-4, pp. 197-227, 2001.

[11] İ. Diler, H. Sevgili, M. Arabac1, and Y. Emre, "Soya İçerikli Gökkuşağı Alabalığı (Oncorhynchus mykiss) Yemlerine İlave Edilen Enzimlerin Büyüme Performansı, Sindirilebilirlik ve Azot-Fosfora İlişkin Çevresel Etkilerinin Belirlenmesi (determination of environmental effects related to growth performance, digestibility and nitrogen-phosphorous of enzymes added to soybean-based feeds of rainbow trout (Oncorhynchus mykiss) feeds)," Ekoloji, vol. 21, no. 85, pp. 89-97, 2012.

[12] A. Pointilart, A. Fourdin, and N. Fontaine, "Importance of cereal phytase activity for phytate phosphorus utilization by growing pigs fed diets containing triticale or corn," Journal of Nutrition, vol. 117, no. 5, pp. 907-913, 1987.

[13] L. Portz and F. Liebert, "Growth, nutrient utilization and parameters of mineral metabolism in Nile Tilapia Orechromis niloticus (Linnaeus, 1758) fed plant-based diets with graded levels of microbial phytase," Journal of Animal Physiology and Animal Nutrition, vol. 88, no. 9-10, pp. 311-320, 2004.

[14] D. Debnath, A. K. Pal, and N. P. Sahu, "Effect of dietary microbial phytase supplementation on growth and nutrient digestibility of Pangasius pangasius (Hamilton) fingerlings," Aquaculture Research, vol. 36, no. 2, pp. 180-187, 2005.
[15] L. Cao, W. Wang, C. Yang et al., "Application of microbial phytase in fish feed," Enzyme and Microbial Technology, vol. 40, no. 4, pp. 497-507, 2007.

[16] B. Zhang, G. He, X. Wang, X. Pi, K. T. N. Mai, and H. Zhou, "Effects of replacing fish meal with soybean meal or fermented and phytase-treated soybean meal respectively on growth performance, feed utilization, and apparent digestibility coefficients in juvenile turbot (Scophthalmus maximus L.)," The Israeli Journal of Aquaculture-Bamidgeh, vol. 68, pp. 1283-1291, 2016.

[17] D. Lemos and A. G. J. Tacon, "Use of phytases in fish and shrimp feeds: a review," Reviews in Aquaculture, vol. 9, no. 3, pp. 266-282, 2017.

[18] P. H. Selle, V. Ravindran, A. J. Cowieson, and M. R. Bedford, "Phytate and phytase," in Enzymes in Farm Animal Nutrition, M. Bedford and G. Partridge, Eds., pp. 160-205, CABI, Oxfordshire, UK, 2nd edition, 2001.

[19] Y. H. Yang, Y. Y. Wang, Y. Lu, and Q. Z. Li, "Effect of replacing fish meal with soybean meal on growth, feed utilization and nitrogen and phosphorus excretion on rainbow trout (Oncorhynchus mykiss)," Aquaculture International, vol. 19, no. 3, pp. 405-419, 2011.

[20] S. Haghbayan and M. Shamsaie Mehrgan, "The effect of replacing fish meal in the diet with enzyme-treated soybean meal (HP310) on growth and body composition of rainbow trout fry," Molecules, vol. 20, no. 12, pp. 21058-21066, 2015.

[21] G. A. Morales, V. Denstadli, S. A. Collins, L. T. Mydland, F. J. Moyano, and M. Overland, "Phytase and sodium diformate supplementation in an plant based diets improves protein and mineral utilization in rainbow trout (Oncorhynchus mykiss)," Aquaculture Nutrition, vol. 22, no. 6, pp. 1301-1311, 2016.

[22] N. O. Yigit and E. Keser, "Effect of cellulase, phytase and pectinase supplementation on growth performance and nutrient digestibility of rainbow trout (Oncorhynchus mykiss,Walbaum 1792) fry fed diets containing canola meal," Journal of Applied Ichthyology, vol. 32, no. 5, pp. 938-942, 2016.

[23] F. Wang, Y. H. Yang, Z. Z. Han, H. W. Dong, C. H. Yang, and Z. Y. Zou, "Effects of phytase pretreatment of soybean meal and phytase-sprayed in diets on growth, apparent digesitbility coefficient and nutrient excretion of rainbow trout (Oncorhynchus mykiss walbaum)," Aquaculture International, vol. 17, no. 2, pp. 143-157, 2009.

[24] G. W. Vandenberg, S. L. Scott, and J. Noue, "Factors affecting nutrient digestibility in rainbow trout (Oncorhynchus mykiss) fed a plant protein-based diet supplemented with microbial phytase," Aquaculture Nutrition, vol. 18, no. 4, pp. 369-379, 2012.

[25] J. Dalsgaard, K. S. Ekmann, P. B. Pedersen, and V. Verlhac, "Effect of supplemented fungal phytase on performance and phosphorus availability by phosphorus-depleted juvenile rainbow trout (Oncorhynchus mykiss) and on the magnitude and composition of phosphorus waste output," Aquaculture, vol. 286, no. 1-2, pp. 105-112, 2009.

[26] V. Verlhac-Trichet, J. Vielma, J. Dias, P. Rema, E. Santigosa, and T. Wahli, "The efficacy of a novel microbial 6-phytase expressed in Aspergillus oryzae on the performance and phosphorus utilization of cold-and warm-water fish: rainbow trout, Oncorhynchus mykiss, and Nile tilapia, Oreochromis niloticus," Journal of the World Aquaculture Society, vol. 45, no. 4, pp. 367-379, 2014.

[27] N. Ö. Yiğit, S. B. Koca, B. I. Didinen, and I. Diler, "Effect of $\beta$-mannanase and galactosidase supplementation to soybean meal based diets on growth, feed efficiency and nutrient digestibility of rainbow trout, Oncorhynchus mykiss 
(walbaum)," Asian-Australas Journal of Animal Sciences, vol. 27, no. 5, pp. 700-705, 2014.

[28] P. Sardar, H. S. Randhawa, M. Abid, and S. K. Prabhakar, "Effect of dietary microbial phytase supplementation on growth performance, nutrient utilization, body compositions and haemato-biochemical profiles of Cyprinus carpio (L.) fingerlings fed soyprotein-based diet," Aquaculture Nutrition, vol. 13, pp. 444-456, 2007.

[29] J. W. Hertrampf and F. Piedad-Pascual, Handbook on Ingredients for Aquaculture Feeds, Klumer Academic Publishers, Norwell, MA, USA, 2000.

[30] AOAC, "Protein content in meat," in (928.08). Official Method of Analysis, , Association of Official Analytical Chemists, Rockwile, MD, USA, 17th edition, 2002.

[31] S. Y1lmaz and S. Ergün, "Trans-cinnamic acid application for rainbow trout (Oncorhynchus mykiss): I. Effects on haematological, serum biochemical, non-specific immune and head kidney gene expression responses," Fish \& Shellfish Immunology, vol. 78, pp. 140-157, 2018.

[32] S. Y1lmaz and S. Ergün, "Effects of garlic and ginger oils on hematological and biochemical variables of sea bass Dicentrarchus labrax," Journal of Aquatic Animal Health, vol. 24, no. 4, pp. 219-224, 2012.

[33] C. A. C. Castro, L. Héctor, M. A. F. Araiza, T. R. Pérez, and O. A. Lopez, "Effects of diets with soybean meal on the growth, digestibility, Phosphorus and Nitrogen excretion of juvenile rainbow trout Oncorhynchus mykiss," Hidrobiológica, vol. 21, no. 2, pp. 118-125, 2011.

[34] R. Jalili, A. Tukmechi, N. Agh, F. Noori, and A. Ghasemi, "Replacement of dietary fishmeal with plant sources in rainbow trout (Oncorhynchus mykiss), effect on growth performance, immune responses, blood indices and disease resistance," Iranian Journal of Fisheries Sciences, vol. 12, no. 3, pp. 577-591, 2013.

[35] M. E. Barnes, M. L. Brown, and K. A. Rosentrater, "Juvenile rainbow trout responses to diets containing distillers dried grain withsolubles, phytase, and amino acid supplements," Open Journal of Animal Sciences, vol. 2, no. 2, pp. 69-77, 2012.

[36] M. A. A. Noraga, A. M. El-Shenawyb, S. E. Fadl et al., "Effect of phytase enzyme on growth performance, serum biochemical alteration, immune response and gene expression in Nile tilapia," Fish and Shellfish Immunology, vol. 80, pp. 97-108, 2018.

[37] A. E. Shehab, M. Z. Kamelia, N. E. Khedr, E. A. Tahia, and F. A. Esmaeil, "Effect of dietary enzyme supplementation on some biochemical and hematological parameters of Japanese quails," Journal of Animal Science Advances, vol. 2, no. 9, pp. 734-739, 2012.

[38] L. Liu, Y. Luo, X. F. Liang, W. Wang, and J. Wu, "Effects of neutral phytase supplementation on biochemical parameters in grass carp, Ctenopharyngodon idellus, and gibel carp, Carassius auratus gibelio, fed different levels of monocalcium phosphate," Journal of the World Aquaculture Society, vol. 44, no. 1, pp. 56-65, 2013. 